\title{
Horizontally Shifted and Vertically Superimposed Ancient Cities: Comparing Urban Histories of Chang'an and Rome ${ }^{1}$
}

\author{
By Meng-chi Hsueh ${ }^{*}$
}

This article compares the forming and transforming process of two grand ancient capitals, Chang'an and Rome. Chang'an had been chosen as the capital of ancient China for many occasions. Repeated relocation had left Chan'an with a series of former sites widely distributed. By contrast, the urban cores of Rome had never moved faraway but remained within a confined area. It is observed that the historic city of Rome tend to be superimposed vertically instead of being horizontally scattered like Chang'an.

This paired intriguing phenomenon makes the researcher wonder why and how these differences were made in the two millennium-old cities' urbanization process. This study delves into the cause and mechanism of their unique development manners by comparing site selection procedures and the temporal-spatial configuration of each city respectively. Three aspects of proposition have been identified as critical to the cause of such dissimilarities, namely ideological thinking, practical consideration, and construction materials.

\section{Introduction}

This article aims at comparing the formation and transforming process of two grand ancient capitals, Chang'an in China and Rome in Italy. Both of them have been used for more than two and a half millenniums, continuously, without complete abandonment but having their urbanized territory shrunk due to the decline of the respective empires. Both the two worldly famous and influential capitals have been the heart of great unified empires, which granted them symbolical importance in each civilization. While Rome was known as the eternal city that embraced enduring prosperity by constructing with imperishable materials, deemed as ideal classics, Chang'an was seen as the spiritual hometown and the root of Chinese civilization. A long history of being capitals enabled Chang'an and Rome to become hybridized and collaged with remnants and memories dated back to various times.

1. This research has been sponsored by the Ministry of Science and Technology (Taiwan), project number MOST 104-2410-H-029-046.

* Assistant Professor, Department of Architecture, Tunghai University, Taiwan. 


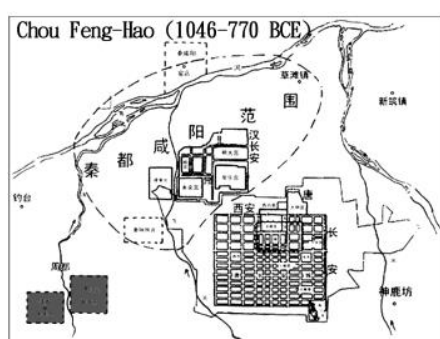

Sui-Tang Chang' an (583-904-CE) $7=$
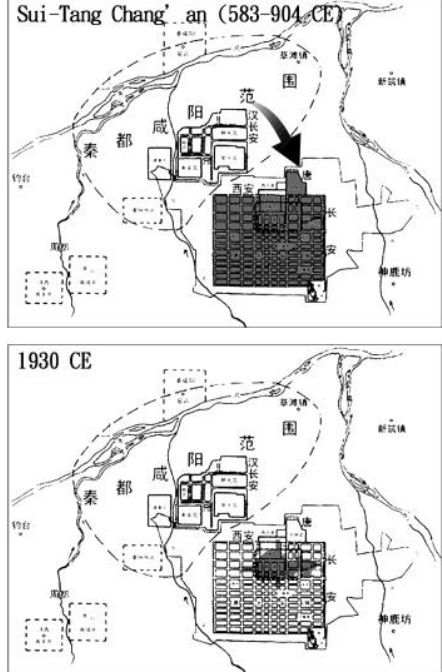
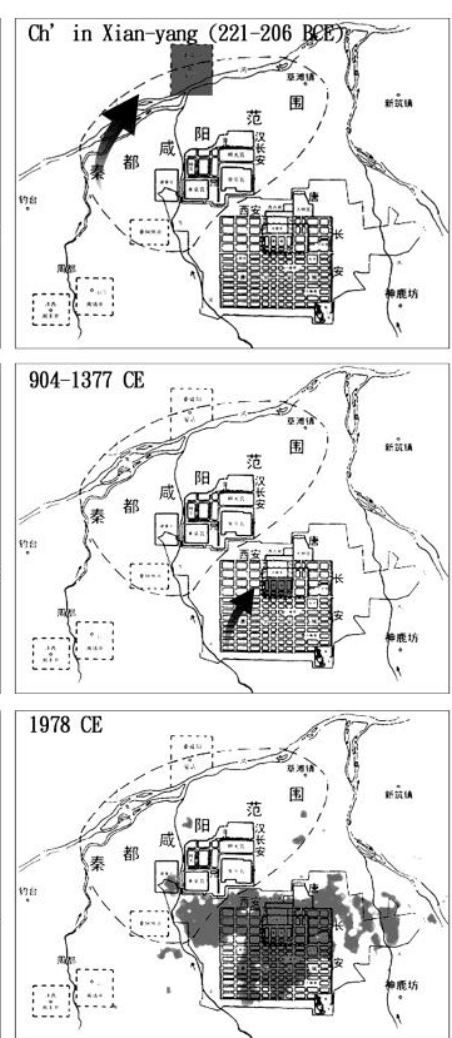
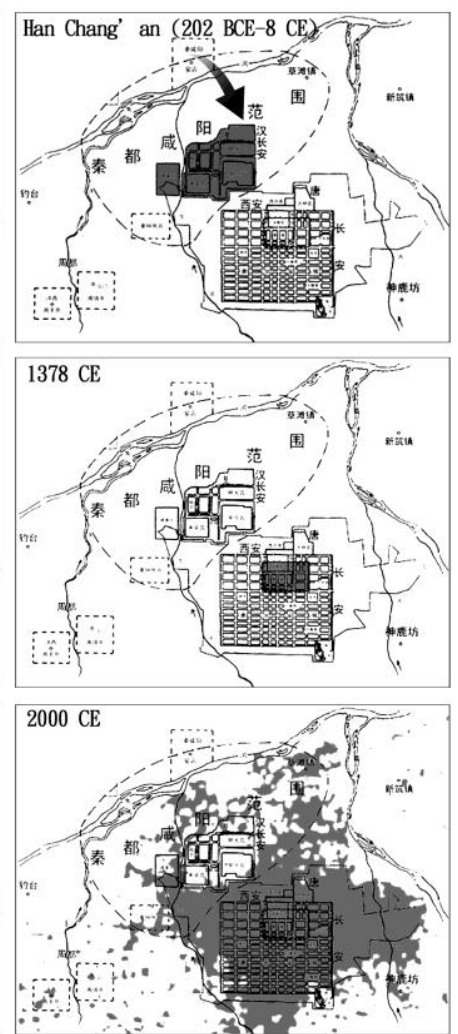

Figure 1. The Shifts of Ancient Chinese Capitals in the Guanzhong Region

Source: For the underlaid map see Wang Xueli, 2007: 4. Contemperary Land Satellite imageries were retrieved from Zhang Hailong et al., 2006: 74; He Yanjie et al., 2009: 50 and compiled by the author.

There were in fact serial capitals of Chang'an horizontally distributing over the Guanzhong region (see Figure 1), ${ }^{2}$ whereas stratigraphic layers of Rome throughout history were vertically superimposed around a specific center (see Figure 2). Such contrasting consequences were unique yet typical of each experience of urban developments. ${ }^{3}$ Investigating on this paired phenomenon comparatively will inspire and enrich our understanding about the evolving patterns of historic cities from the ancient to the present. Considering the

2. See Figure 1 for detailed names of these ancient capitals and the shifts of their sites. Chang'an is the old name of the contemporary Xi'an municipal city in the Province of Shaanxi, China. Situated on the Guanzhong basin, Xi'an is one single city that incorporates into more than one ancient capital within its territory. Each ancient capital has its own name. In order not to confuse the readers, this article uses Chang'an as an umbrella term for the group of cities that located within contemporary Xi'an. Since the sack in the end of the Tang dynasty (904 CE exactly), Chang'an has never been the capital of China again but was downgraded as a local city. The official name of Chang'an was changed to Xi'an in $1369 \mathrm{CE}$.

3. Nowadays a modern city that comprised the remnants of several former capitals can find resemblances among the most important Chinese ancient capitals, such as Beijing and Luoyang. Layered relics could be seen in Kaifeng and other villages along the Yellow River. Within the reach of the former Roman Empire, Some new cities were retained and redeveloped on the old Roman spatial configuration, such as London, Milan, Lyon, Paris, Koln, and Vienna. There were also medieval cities that chose not to build upon the ruins but to relocate out of them. 
epochs that both cities underwent most of the transformation, this article primarily focuses on the periods from the inauguration of the cities to the $9^{\text {th }}$ century CE. ${ }^{4}$ Chang'an was chosen to be the capital of at least 13 Chinese dynasties successively. More precisely, it is observed that the historic capital(s) of Chang'an have been relocated several times, each new site not far from the preceding forsaken ones. By contrast, the urban cores of Rome that were established and renovated in various historical eras had always remained within a confined area which was later enclosed by the Aurelian Wall.

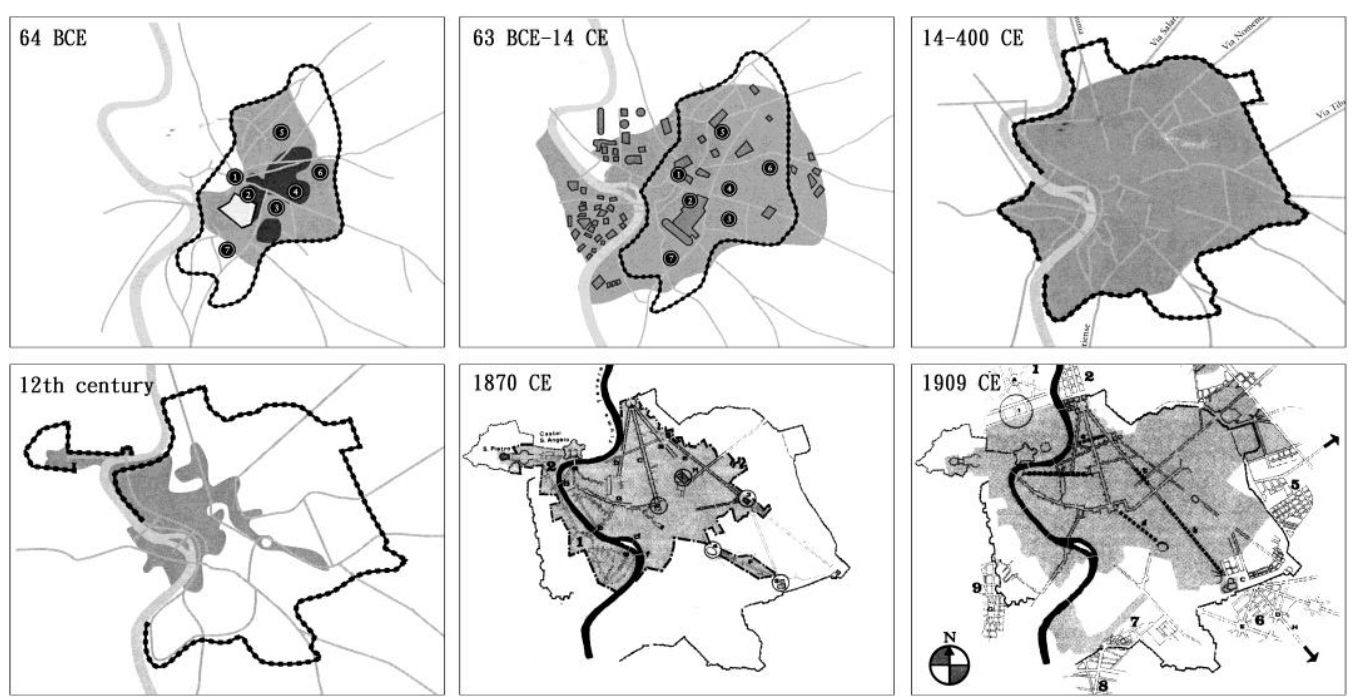

Figure 2. The Transition of Urbanized Areas in Rome throughout History Source: F. Archibugi, 2015.

This couple of horizontally dispersed versus vertically superimposed ancient capitals makes the researcher wonder why and how these differences were made in the two millennium-old cities' urban histories as well as how these evolving patterns would further impact the contemporary urbanization process (see Figure 3). Beginning with such an observation, this article attempts to delve into the cause and mechanism of their unique development manners by comparing site selecting procedures and the temporal-spatial configuration of each city respectively. Three aspects of proposition that are crucial to such dissimilarities, have been identified, namely ideological thinking (which reflects on various definitions towards the idea of a city), practical consideration (for living through the tension between water and land), and construction materials (constructing eternity in stone versus planning ephemerality with decomposable materials). This article not merely sheds light on the evolvement of each urban form but also puts forward the need to reconsider the definitions of the city and its architecture, which are critical to

4. It was the time when Chang'an not only ceased to be the capital once and for all, but also put an end to its relocation journey. It was also when Rome was transformed into the capital of the Papal State after it lost its status of being a capital in the end of the Roman Empire half a millennium ago. 
how we perceive the conservation and resilience of the city based on cultural diversity.

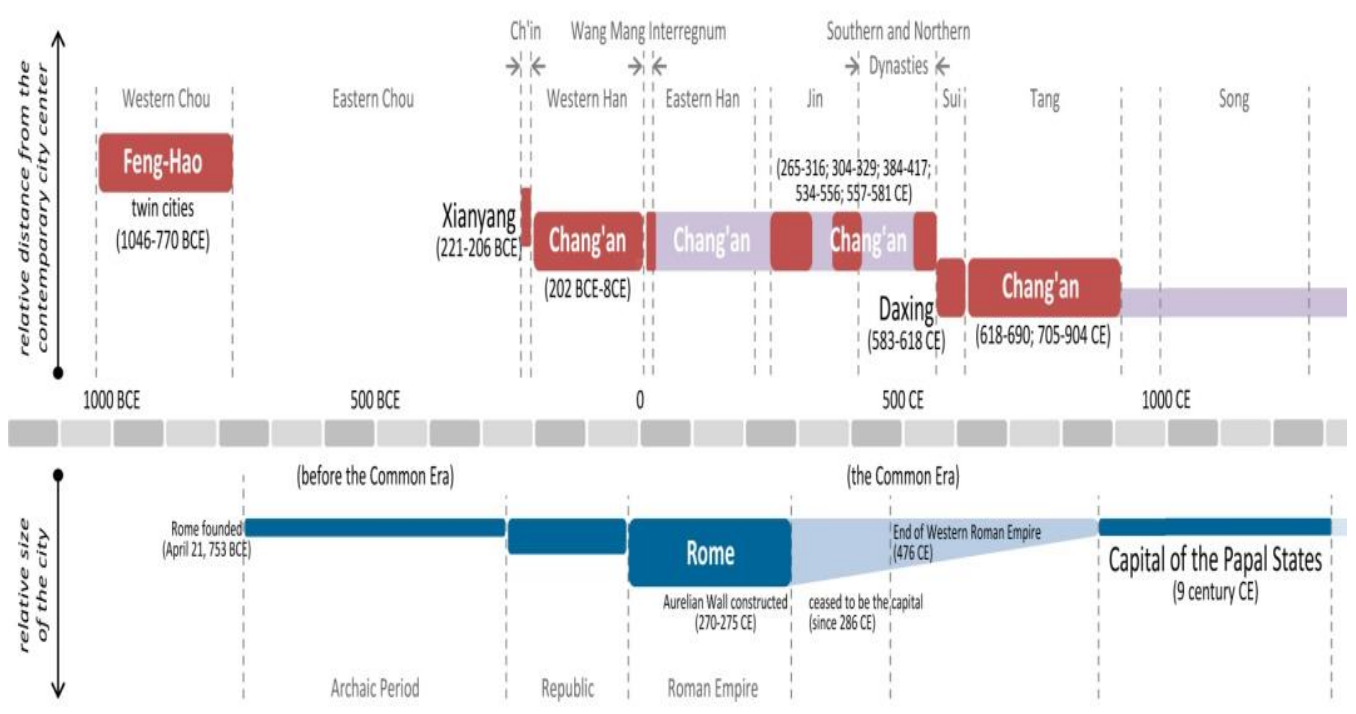

Figure 3. Comparative Timeline of the Development of Chang'an and Rome (Capitals Are Marked In Darken Background)

Source: Author.

\section{Ideological Thinking: Various Ideas of a City}

For both the ancient Chinese and the ancient Romans, rational analysis has never been the only criteria for determining where to establish their major cities. Intangible and symbolic consideration seemed to play a significant, if not a dominant, role in each divinatory site selecting procedure. Either by geomancy, the milfoil and the tortoiseshell (in ancient China) or via hepatoscopy (in ancient Rome), observing horoscope and omens (in both), mystical means were employed respectively to ensure that the location chosen for the proposed city was under favorable auspices. ${ }^{5}$ Although sharing similar thoughts in seeking heavenly advice and trying to be "consonant with the natural order," ${ }^{6}$ the divergent results of the site(s) selection manifest that the two ancient civilizations possessed various ideas of what constitutes a city. The

5. For detailed ritual procedures of seeking for oracles, choosing a site, orientation and disposition in constructing Roman cities, see Joseph Rykwert, The Idea of a Town: The Anthropology of Urban form in Rome, Italy and the Ancient World (London: Faber and Faber, 1976), 44-49. For ancient Chinese cities see Arthur F. Wright, "The Cosmology of the Chinese City," in The City in Late Imperial China, ed. William G. Skinner (California: Stanford University Press, 1977), 35-39, and 46-48.

6. Arthur F. Wright, "Symbolism and Function: Reflections on Chang'an and Other Great Cities," The Journal of Asian Studies, 4 (1965): 669-670. 
one and only Rome has never been away from its legendary center (Caput Mundi, capital of the world) even after ceasing to be the Capital; on the other hand, constant relocation has produced a series of Chinese royal capital(s) scattering in the Guanzhong region.

Constructing an eternal city or settling in one permanent capital is not a Chinese idea. In reality, multiple capitals or metropolis, which made migration much easier, were common in the Chinese urban regime. Feasibility of logistics, military defense or rebellion, ethnic custom, political influence of domestic clans, as well as periodical climate change were potential factors that prompted Chinese monarchs and his intimate courtiers to make the decision of moving from one capital to another. Even if the monarch made his mind to move to an already existing city, the exact location and layout of such a city would not necessarily be retained. This was true, especially when a successor overthrew the previous government and established a united empire anew. Ideally and ideologically, the most triumphant challengers were eager to wipe out any symbols or memories related to the former dynasty, royal palaces, and capital. Only if it was financially realizable, a new walled capital would be constructed to substitute for the old one. In demarcating the new capital, normally the territory of the former capital in ruins was carefully avoided since the ancient Chinese regarded the past history of being defeated as a sign of misfortune. Ideology as such was distinct from ancient Rome.

Furthermore, the construction of the Chinese capital was commissioned by the monarch who claimed to be "the Son of Heaven" (tian-zi), that was to say, the one who acted for heavenly deities in ruling the world of mortals. ${ }^{7}$ The ideal spatial configuration of the capital, and only the monarch's capital was arranged as an imitation of the constellations. The royal palace positioned in the center was a symbolic representation of "the monarch as a terrestrial ruler and cosmic pivot" ${ }^{8}$ surrounded and supported by the subordinate. For ancient Chinese who believed in the "mandate of heaven", anyone who successfully came to power had divine right. ${ }^{9}$ For reaffirming or justifying his status, the

7. Such Confucianism ideology regarding to the monarch's heavenly mandate has been best elaborated by ancient Chinese philosopher Dong Zhongshu (195-104 BCE). See Dong Zhongshu, Chunchiu Fanlu [Luxuriant Gems of the Spring and Autumn] (Hefei: Huangshan shushe, [second century BCE] 2008), vol. 10, 49 (section 35 "Shen cha ming hao" [Deeply Examine Names and Designations]) and vol 11, 54 (section 41 "Wei ren zhe tian" [Heaven, the Maker of Humankind]).

8. Arthur F. Wright, "Symbolism and Function: Reflections on Chang'an and Other Great Cities," The Journal of Asian Studies, 4 (1965): 671.

9. Related governance philosophy see Confucianism scholar Dong Zhongshu, Chunchiu Fanlu [Luxuriant Gems of the Spring and Autumn] (Hefei: Huangshan shushe, [second century BCE] 2008), vol 8, 43-44 (section 30 "Bi ren qie zhi" [The Necessity of Being Humane and Wise]) and vol 16, 80-83 (section 77 "Xun tian zhi dao" [Conform to Heaven's Way]). Many historical archives have details about how each Chinese tian-zi determined to move to the new site of his capital and commission its construction. For Chou Feng-hao twin cities, see "Wenwang you sheng" [King Wen is famous], in Xinyi Shijing duben [Reader of the Book of Odes, with new annotations and translation in Chinese], ed. Teng Chixian (Taipei: Sanmin Shuju, [11th to 6th century BCE] 2006), 799-805. For Han Chang'an, see Sima Qian ed., "Liouhou shijia" [Marquis of Liu], in Shiji [Records of the Grand Historian] (Hefei: Huangshan shushe, [91 BCE] 2008), vol. 55, 675. For the relocation of Sui Daxing, see Wei 
succeeding monarch was willing to employ the canonical prescription to properly orientate and sanctify his own new capital. This explains the reason why there could be a sequence of capitals and associated "centralities" in the Guanzhong region. Each centrality was enclosed individually and was granted a different "cosmicizing" ${ }^{10}$ symbolic meaning.

In contrast to Chinese temporal and relative centrality, the ancient Romans embraced the idea of an invariable and absolute center, namely Umbilicus Urbis or Mundus. To the ancient Romans, a city by definition was where the deities inhabit forever. Deities were omnipresent in the city, as Roman historian Livy (Titus Livius, 64 or $59 \mathrm{BCE}$ to $17 \mathrm{CE}$ ) described, a kind of "a reciprocal engagement" was established between gods and men. ${ }^{11}$ As a result, even if it was sacked or ruined, the citizens would not forsake their city as long as the deities stayed. ${ }^{12}$ A Roman city is sacred by nature for the reason that, a city could not come into being until canonical rituals had been properly performed. ${ }^{13}$ Not only the exact center and boundary, but also the pomerium, of the city were determined by divine providence. The rites of founding the city were reiterated annually through festivals in order to rejuvenate the celestialterrestrial connection.

The Roman city was built for the citizens' interests rather than primarily the state's concern. Hence it was inaugurated publicly with the community's consensus and participation. In ancient times, the birthday of the city of Rome was highly valued and celebrated. Memories about the legendary founder and the founding event were recalled while the celebration procession took place along the symbolic territory of the city during ritual festivals such as Amburbalia (festival of the city enclosure), Ambarvalia (of the territorial limits), Terminalia, Lupercalia (where the she-wolf found the twins), dies Fabruatus, the dance of the Salian brothers, as well as Rome's birthday. ${ }^{14}$ The

Zheng ed., "Gaozu benji" [Annals of Emperor Gaozu], in Sui shu [Book of Sui] (Hefei: Huangshan shushe, [636] 2008), vol. 1, 9-10.

10. The term is from Mircea Eliade, The Sacred and the Profane (New York: Harcourt Brace Jovanovich, [1959] 1961), 30-32. For the Chinese idea of "cosmicizing" the city's design, see Arthur F. Wright, "Symbolism and Function: Reflections on Chang'an and Other Great Cities," The Journal of Asian Studies, 4 (1965): 670. For Sui-Tang Chang'an, see Tatsuhiko Seo, Chōan no Toshi Keikaku [City Planning in Chang'an] (Tokyo: Kōdansha, 2001), 138-144.

11. Fustel De Coulanges, The Ancient City: A Study on the Religion, Laws and Institutions of Greece and Rome (Garden City, N.Y.: Doubleday, [1864] 1956), 141.

12. For instance, the citizens refused to abandon the ruins of Rome, which has been devastated by the Gauls, and remove to Veii. See Fustel De Coulanges, The Ancient City: A Study on the Religion, Laws and Institutions of Greece and Rome (Garden City, N.Y.: Doubleday, [1864] 1956), 141-142.

13. A city is not only a tangible entity. Similarly, corresponding rituals should be executed to make a city completely disappear. See Joseph Rykwert, The Idea of a Town: The Anthropology of Urban form in Rome, Italy and the Ancient World (London: Faber and Faber, 1976), 201-202.

14. For more details of the festivals and associated meaning, see Fustel De Coulanges, The Ancient City: A Study on the Religion, Laws and Institutions of Greece and Rome (Garden City, N.Y.: Doubleday, [1864] 1956), 159; Rodolfo Lanciani, The Ruins and Excavations of Ancient Rome (Boston and New York: Houghton, Mifflin and Company, 1897), 129-130; 
routes and the choreography of public parades actually served to repeatedly strengthen the citizens' understanding of the history and topography of the city. ${ }^{15}$ However, except the city's birthday, dates of certain Roman festivals were not fixed but were different from one city to another since the calendar was regulated neither by the course of the sun nor the moon but by the law of religion. ${ }^{16}$ It seemed that the Roman way of celebration was more placespecific rather than time-relevant. Moreover, bodily experiences may perennially refresh or create citizens' memory of historic urban events and repeatedly enhance their sense of belonging to the city. Conversely, Chinese religious festivals were tied firmly to the agricultural seasons. ${ }^{17}$ It was the monarch, as "the Son of Heaven", who had the exclusive obligation to institute a universal calendar for his people to follow. Unlike the Romans, the ancient Chinese seemed to pay more attention on explicit dates than places for performing ritual ceremonies. ${ }^{18}$ Irrelevancy or no attachment to one irreplaceable place conformed to the temporality of Chinese capitals.

This section explains why the city of Rome persisted to stay while the Chinese capitals were prone to move comparatively from the ideology of the two ancient civilizations. Nevertheless, why and how were the layered cities of Rome generated? In other words, what was the mechanism that made Rome not only to stick to one place but stack upon more antique ones? Relatively, what triggered the serial capitals in the Guanzhong region for relocation? Was there any logic in the pattern of movements? For answering these questions, we need to take one step forward and investigate the relationship between the city and its natural environment respectively.

\section{Practical Consideration: Surviving the Floods}

Rivers are critical factors in locating human settlements, for a livable city should not be distant from adequate supplies of water and food, with ease of transportation, and in the meantime be safe from disastrous floods. It seems a natural dilemma that being close to the river may make the city vulnerable to floods. The sites of serial capitals in the Guanzhong region were greatly

Joseph Rykwert, The Idea of a Town: The Anthropology of Urban form in Rome, Italy and the Ancient World (London: Faber and Faber, 1976), 91-96.

15. Diane Favro, "The Street Triumphant: The Urban Impact of Roman Triumphal Parades," in Streets: Critical Perspectives on Public Space, ed. Zeynep Çelik, Diane Favro, and Richard Ingersoll (Berkeley: University of California Press, 1994), 155 and 160.

16. Fustel De Coulanges, The Ancient City: A Study on the Religion, Laws and Institutions of Greece and Rome (Garden City, N.Y.: Doubleday, [1864] 1956), 159-160. See also Annie Dubourdieu, "The Roman Calendar: How Did the Ancient Romans Spend their Time," in Rome-Han: Comparer l'Incomparable, ed. Marianne Bujard and Marc Kalinowski (Beijing: Zhonghua Book Company, 2011), 335 and 337-338.

17. Henri Maspero, China in Antiquity (Amherst: University of Massachusetts Press, [1927] 1978), 132.

18. Although certain attributes were prescribed, Chinese ritual settings showed more flexibility that designated types of space or building complex could be duplicated or rebuilt along with the relocation of new capitals, only if it was on the relatively right direction. 
influenced by the Weihe River and eight of its tributaries. Similarly, the evolution of Rome was confined by the Tiber River. It is observed that the movements of the Chang'an capitals have moved it farther and farther away from the Weihe River, that is to say, less and less prone to flood. On the contrary, the eternal city of Rome's resistance to move did not guarantee the site as a naturally safe and perfect one. Actually, Rome has never escaped from the threat of inundation even at the present day.

The first capital in the Guanzhong region should date back to the Chou dynasty in the eleventh century BCE. The twin cities Feng and Hao (1046-770 $\mathrm{BCE})$ were in fact named after the tributary they were situated by. Superior accessibility to water was an obvious virtue in determining the site. The second capital arose in this region, Ch'in Xianyang (221-206 BCE), occupied the plateau on the northern bank of the main stream, rather than the tributary, for better dominating militarily important ferry wharfs along the Weihe River. Although the new expanded Xianyang was not far from the river, the water supply on the highlands was still a problem. To make up for this shortage, Xianyang began to expand southwards across the Weihe River. Although Xianyang and Chang'an, the capital of the succeeding empire (from 202 BCE to $8 \mathrm{CE}$ ), both have always occupied the riversides' low-lying lands along the Weihe River, inundation was not that problematic, compared to droughts, until the frequencies of floods and droughts both increased notably since the end of the sixth century CE due to long-term climate change. ${ }^{19}$ This has directly resulted in the abandonment of the old Han capital after being used for eight hundred years.

The next grand capital located in this region was the Sui-Tang Chang'an (583-904 CE). Environmental issues were vital concerns, along with ideological and political reasons, in making the decision of discarding the old Han Chang'an and constructing a new one nearby. In addition to being submerged in Emperor Wen's legendary nightmare, the old capital has been too deteriorated to inhabit and its groundwater too contaminated to drink as a result of repeated warfare. ${ }^{20}$ And most importantly, the flood-prone area could no longer carry the weight of large building complexes. From the sixth century onwards, such floods occurred more frequently, so shifting the capital elsewhere eventually became inevitable. It has been widely accepted that each relocation of the new capital has made it superior than the previous ones. And only if the water provision technique was advanced, which also signified humans' upgraded capability of adapting to the nature, could the capitals move to higher and drier grounds. Viewing from the pattern of serial relocation, Chang'an endeavored to balance against the dilemma of accessibility to water

19. For statistics bar graph see Qiu Lihui, Gudai huanghe zhongyou dushi fazhan qianyi yu huanjing bianhua yanjiou [City Development-Relocations and Environment Changes in the Middle Reaches of the Yellow River in History], Ph. D. diss. (University of Shaanxi Normal University, 2008), 96.

20. See Wei Zheng ed., "Gaozu benji" [Annals of Emperor Gaozu], in Sui shu (Hefei: Huangshan shushe, [636] 2008), vol. 1, 9-10. 
resources and the potential inundation as opposed to Rome's continually living with the floods.

To the ancient Romans, by contrast, floods were taken more as oracles or portents than simply vicious catastrophes that inhabitants could or should normally avoid or actively take effective measures of remedy. ${ }^{21}$ In fact, Rome was doomed for routine inundation ${ }^{22}$ since the very moment of its legendary birth. The life of Romulus, the founder of Rome, was saved by the fatal flooding as Gregory S. Aldrete stated it as "the divinely directed floodwaters functioned as the agent who selected the actual site of Rome". ${ }^{23}$ Being situated right on the floodplain and having the most important symbolic center submerged in water ${ }^{24}$ was therefore not a coincidental outcome. In other words, the ancient Romans did not choose the site in proximity to the river primarily out of water availability as their Chinese counterpart did. Frequent inundation indeed affected but did not jeopardized most of the citizens' daily lives for the following reasons. First of all, casualties could be alleviated because the highly uneven topography of Rome made it possible to take refuge quickly on nearby higher grounds as the Tiber rose. Moreover, fresh potable water could still be delivered via aqueducts from distant mountains while major bathhouses on the highland were still in function and shelters were provided during and after the inundation. ${ }^{25}$ Those conditions found no analogue in any of the Chang'an capitals, which not only relied on river and canal water, well, lakes or groundwater but also lacked similar types of public buildings. All such distinctions that made submersion less unendurable to the Romans might help to partly explain why they never thought of escaping from or fighting against the threat but making up their minds to live out the floods in peace.

While flooding was seemingly accepted as part of the urban life in Rome, it physically brought about other circumstances, namely the alteration of natural topography and the built environment. If submerged in water the buildings would become structurally unstable, their deteriorating process would accelerate, and they could even collapse. When the water receded, silt left by the floods was too difficult to be cleaned up that it usually remained on the site and became a new ground level for succeeding construction. Debris, together with silt, rubble, man-made refuse, and other aggregated fill, gradually filled up the valley, continually raised the ground, and buried lower parts of buildings. In addition to flooding, accumulation produced by other forms of

21. Gregory S. Aldrete, Floods of the Tiber in Ancient Rome (Baltimore: Johns Hopkins University Press, 2007), 219-225.

22. For detailed information and list of major floods at Rome from 414 BCE to $2000 \mathrm{CE}$, see Gregory S. Aldrete, Floods of the Tiber in Ancient Rome (Baltimore: Johns Hopkins University Press, 2007), 242-246.

23. Gregory S. Aldrete, Floods of the Tiber in Ancient Rome (Baltimore: Johns Hopkins University Press, 2007), 12.

24. For city regions that were prone to be inundated, see Aldrete's analysis on ancient Rome's floods and topography shown in serial maps. Gregory S. Aldrete, Floods of the Tiber in Ancient Rome (Baltimore: Johns Hopkins University Press, 2007), 44-48.

25. For more explanation see Gregory S. Aldrete, Floods of the Tiber in Ancient Rome (Baltimore: Johns Hopkins University Press, 2007), 210-211, and 232-239. 
calamities such as the ashes of erupting volcanoes, dirt carried by sandstorms, debris caused by conflagrations and earthquakes all were responsible for generating the superimposed layers that are nowadays beneath the modern city of Rome. The uplift of artificial ground could be unplanned or purposeful since the raised floor would certainly keep facades more visible above standing crowds in the triumphal parades ${ }^{26}$, or at least help to alleviate the damages induced by future floods. For instance, as much as eight successive layers of paving exhibited the elevation of the originally low-lying Roman Forum. ${ }^{27}$ In reality, the historical center of Rome is covered with a layer of uniformly thick accretion. An enormous quantity of man-made debris up to 93 million cubic meters was piled up within the enclosure of the Aurelian Walls with an average thickness ranging from 2 to 5 meters (6.6 to 16 feet) ${ }^{28}$ Deposits more than 15 meters (49 feet) in depth, being filled as the base for construction or simply generated by dumping, were not an unusual scene. ${ }^{29}$ The Basilica of San Clemente in Rome, situated at the very bottom of a ravine, was such a case that demonstrated the superimposition of at least three large complexes of various historical periods. The lowest level of building complex, datable to the first century BCE, is 14 meters (45 feet) under the level of the medieval basilica. It is inspiring to see that, comparatively, the stratum of the Tang dynasty (circa seventh to ninth century $\mathrm{CE}$ ) is merely 0.7 meter below the present street level.

\section{Material Aspect: Constructed Eternity versus Planned Ephemerality}

Ancient Chinese and Roman contrasting attitudes towards the relationship between the capital and its watery surroundings should also be understood from the aspect of the construction materials and associated mentality. This may as well facilitate to clarify the formation of the "horizontally shifted" ancient cities versus the "vertically layered" ones.

Using timber and rammed earth as primary construction materials made the ancient Chinese have no choice but to flee from the floodwaters. Commonly seen Chinese construction materials such as timber, adobe, mud, bamboo, and straw were decomposable and could not resist to immersion. The Chinese traditionally lived in timber framework inlaid with mud and braided bamboo partition walls. For signifying the owner's dignified status, the timber

26. Diane Favro, "The Street Triumphant: The Urban Impact of Roman Triumphal Parades," in Streets: Critical Perspectives on Public Space, ed. Zeynep Çelik, Diane Favro, and Richard Ingersoll (Berkeley: University of California Press, 1994), 158.

27. L. Richardson, A New Topographic Dictionary of Ancient Rome (Baltimore: John Hopkins University Press, 1992). See also Gregory S. Aldrete, Floods of the Tiber in Ancient Rome (Baltimore: Johns Hopkins University Press, 2007), 178.

28. G. Heiken et al., The Seven Hills of Rome: A Geological Tour of the Eternal City (Princeton: Princeton University Press, 2005), 88.

29. For the depth of the layers of accumulated man-made debris, see U. Ventriglia, The Geology of the City of Rome (Rome: Amministrazione Provinciale di Roma, 1971), 87-97; Gregory S. Aldrete, Floods of the Tiber in Ancient Rome (Baltimore: Johns Hopkins University Press, 2007), 39-42. Also refer to U. Ventriglia's map of "Spessore della coltre dei terreni riporto" [Thickness of the layer of soil carryover] in the same book. 
building complexes would be erected on top of massive foundations made of rammed earth. To protect the wooden and earthen parts of the buildings immune from dissolving or decaying, giant straw or terracotta tiled roofs with expanded eaves were required. Nevertheless, the giant roofs could only shed rainwater coming from above but were unconcerned with the ponding that submerged at the foot of the buildings. Since Chinese rammed earth foundations were normally surfaced with plaster yet not entirely coated with kiln-dried bricks before the Ming dynasty (fourteenth to seventeenth century), ${ }^{30}$ flooding would severely undermine their solidity as a whole. Oppositely, being constructed in brick, stone, and concrete made the Roman cities more resistant to damage induced by inundation..

Similar to the consequences of floods that resulted from ancient Roman's inactive countermeasures, the elevated ground and layered urban history should also attribute to constructing in stone. Ancient Romans had such an appetite for marble that emperor Augustus (63 BCE- $14 \mathrm{CE}$ ) even prided himself on successfully transforming Rome from a brick city to a marble one. Augustus's boast implied that stone was not treated as simply a construction material. Stone-built constructions not only make room for utilitarian uses but also set the stage for exhibiting political power as Richard Sennett said that "the realm of certified stone in the city" would literally make the Romans "look and obey an enduring regime". ${ }^{31}$ Romans' continual prestige of marble was out of the desire to construct an "Eternal City". Just because all living creatures would fade away some day, fiction of a durable, continuing and unchanging city was necessary for the Romans. In order to make the ideal of eternity more conceivable and credible, the emperor had to dramatically visualize his powers through repetitive pictorial narration and the construction of imperishable building complexes, which would be best represented in stone. ${ }^{32}$

Both the fever of visualizing eternity in stone-construction and the ultimate abandonment of the once great city resulted in Rome's superimposed urban layers. Monuments and buildings were so concentrated in and around certain places with important symbolic meanings that older erections had to be removed periodically to make room for new incoming ones. ${ }^{33}$ This kind of replacement or reconstruction was never an easy task if not adopting extreme measures. Taking the Baths of Trajan for instance, a leveled-up platform of 317 $\mathrm{m}$ by $332 \mathrm{~m}$ was generated by the dislocation of living quarters within designated area and the partial demolition of an existing palace complex, the

30. See Pan Guxi ed., Zhongguo gudai jianzhu shi [History of Ancient Chinese Architecture] (Beijing: Zhongguo jianzhu gongye chubanshe, 1999), 457.

31. Richard Sennett, Flesh and Stone: The Body and the City in Western Civilization (New York: W.W. Norton, 1994), 91, 96-97.

32. Richard Sennett, Flesh and Stone: The Body and the City in Western Civilization (New York: W.W. Norton, 1994), 91, 96. See also Rolf M. Schneider, "Image and Empire: The Shaping of Augustan Rome," in Conceiving the Empire: China and Rome Compared, ed. FritzHeiner Mutschler and Achim Mittag (Oxford: Oxford University Press, 2008), 277.

33. Diane Favro, "The Street Triumphant: The Urban Impact of Roman Triumphal Parades," in Streets: Critical Perspectives on Public Space, ed. Zeynep Çelik, Diane Favro, and Richard Ingersoll (Berkeley: University of California Press, 1994), 159. 
Domus Aurea (the Golden House). ${ }^{34}$ The remnants of the Domus Aurea were then buried underground and reused as the foundation for the new bath complex. Constructing in masonry definitely made such a transformation and superimposition especially feasible since bricks, rubble, as well as concrete relics could be aggregated easily and well integrated to form a stable stratum. And judging from the structural aspect, the superimposed upper construction could be built with or without regard to the underground mass.

Also worth mentioning was the fact that the collapse of rapidly built roughcast insulae (4-5 storied apartments) was not rarely seen in this densely populated capital. Considering the amount and weight of all such debris, the ancient Romans usually chose not to empty it out but build right upon it. Moreover, as many buildings fell into disuse due to the decrease of the population in medieval Rome, indifference to the imperial ruins further increased the thickness of man-made debris. When the once highly appraised sites with stone construction were degraded as quarries, the dismantling of the metal joints, that originally served to fasten each piece of stone component together, accelerated the crumbling of the already dilapidated structures. From late Antiquity to the Middle Ages, more mounds of debris were thus generated and new routes emerged on top because the inhabitants took shortcuts to pass through the ruins. ${ }^{35}$ It was supposedly because of the availability of spolia, which meant the reuse of earlier architectural components, that medieval Rome did not move away. Marble and tufo, taken from imperial monuments, were reused in new buildings for sure although they could also be transported faraway. A sense of superiority and symbolic meaning associated with using stone, especially marble, went on as more connotation attached. ${ }^{36}$ Symbolic meanings might evolve over time according to various purposes of reuse. Also important was the facts that several Christian popes endeavored to reorganize and reposition monuments of imperial Rome as landmarks for pilgrimage tourism, thus converted the original pagan association.

Regarding the spiritual tradition and bias toward construction materials, what the ancient Romans excluded was exactly what the ancient Chinese embraced. Although the reason why ancient Chinese used so much timber remains debatable, ${ }^{37}$ it is widely accepted that the Chinese preference for

34. Domus Aurea was built by the notorious emperor Nero in $68 \mathrm{CE}$. Instead of completely torn down the whole structure of Domus Aurea, anything higher than $47 \mathrm{~m}$. above sea level (masl) was demolished while the lower-storied walls and vaults were retained and buried underground.

35. See related exhibition boards in Crypta Balbi, National Museum of Rome. See also Jan Gadeyne, "Short Cut: Observations on the Formation of the Medieval Street System in Rome," in Perspectives on Public Space in Rome, from Antiquity to the Present Day, ed. Smith Gregory and Jan Gadeyne (Burlington, VT: Ashgate, 2013), 67-83.

36. Using spolia was "more likely to have been symbolic than utilitarian, that of repossessing the Roman past." And marble columns were "often regarded as trophies than as utilitarian objects." Both are excerpted from Michael Greenhalgh, The Survival of Roman Antiquities in the Middle Ages (London: Duckworth, 1989), ch. 7.

37. Related debates see Hou Youbin, Chinese Architectural Aesthetics (Beijing: China Building Industry Press, 2009), 5-10; You Shi, "Zhongguo jianzhu buzhi mu" [Chinese Architecture: Not Merely with Timber], The Architect, 6 (2007): 72-73. In reality, the major 
decomposable materials should not be viewed purely as a lack of endurable ones. Clearly, ancient Romans struggled to fictionalize an enduring place that ran counter to the ongoing time flows whereas the ancient Chinese deliberately insisted on building their residences in accordance with the natural life cycle of growth and decay every creature would undergo. That is to say, as Romans invented and crafted eternity, the Chinese conceived and planned ephemerality. ${ }^{38}$ The use of timber was intended to emphasize the sense of liveliness. ${ }^{39}$ And as a result, its consequential decaying was not evaluated as a shortage but eventually transformed to be taken as a sign of correspondence between humanity and the universe.

Ancient Chinese construction was considered as changeable and temporal as clothing and vehicles in Liang Sicheng's description (1901-1972; 1981: 89). ${ }^{40}$ Liang's metaphor of external outfits could be further elaborated as that a building not only satisfied the needs for a functional shelter but also manifested a hierarchical symbol. Based on Confucian moralities and formalities, the scale and complexity of one's dwelling should be upgraded or degraded in order to suitably fit and signify the owner's social status. Judging from the structural and architectonic aspects, wood tenoned framework and module systems certainly have great flexibility for efficient adaptation and reconstruction. Moreover, the physical condition of the residences could be seen as an indicator of whether the family was prosperous or not. Because regular renovation was required for the buildings made of decomposable materials, the house would soon fall into the state of dilapidation if a family had either financial deficiency or no progeny to take charge of maintenance.

The ancient Chinese neither confined themselves to one single capital nor endeavored to construct immortal buildings for the living mortal anyhow. Such mentality had its origins in Chinese conventional beliefs. First of all, Chinese predominant elites were accustomed to advocate metaphysics yet depreciate materiality. And undoubtedly they were disciplined to moderate excessive physical appetites, such as the pursuit of sumptuous and indestructible housing construction. Actually, being aware of the fact that even stone would be rotten in the long run, Chinese literati providently resorted to the texts to have their conduct and imaginarily built architecture archived and handed down forever. ${ }^{41}$ Additionally, it goes without saying that the notion of constructing long lasting

parts of almost all the traditional Chinese dwellings were made of wood no matter how abundant the bricks supply was. And even the most magnificent royal palace was primarily made of wood with no exceptions; just in larger scale, with more complexity, and situated on higher foundation.

38. Arthur F. Wright, "Symbolism and Function: Reflections on Chang'an and Other Great Cities," The Journal of Asian Studies, 4 (1965): 677. See also Michèle Pirazzolit'Serstevens, Living Architecture: Chinese (New York: Grosset and Dunlap, 1971), 12.

39. Han Paothe, Zhongguo de jianzhu yu wenhua [Chinese Architecture and Culture] (Taipei: Lianjing Press, 2004), 17-21.

40. Liang Sicheng, Zhongguo jianzhu shi [History of Chinese Architecture] (Taipei: Mingwen Press, [1944] 1981), 8-9.

41. Guo Weiqi, "Shitou momie zhihou: chaoyue le paifang, citing, shibei de zhishang jianzhu" [When the Stones Effaced: The Fictitious Buildings beyond Paifang, Shrine and Stele], Journal of Chinese Architecture History, 2 (2012): 374-395. 
public spaces in order to win prestige and aggrandize themselves was foreign to Chinese bureaucrats who gained their positions by appointment rather than by votes. Probably inspired by the Buddhism faith, furthermore, there was no need to persist in materiality since the world itself was nothing but an illusion. Instead of constancy, permanence per se resided in constant variation on the basis of Chinese philosophy. Establishing an everlasting "monument" was alien to Chinese concepts. It was spiritual longevity in preference to physical perpetuation the ancient Chinese truly aspired after. The name of the city Chang'an literally signified the Chinese mindset of longing for everlasting happiness and tranquility. Nevertheless, these mental wishes were regarded as nothing to do with immortal materialization. ${ }^{42}$

Employing mainly decomposable materials was the cause that motivated the successive relocation of the capitals in the Chinese Guanzhong region. Due to the same reason, each past capital left comparatively thin layers of debris owing to the decomposition of timber, certainly if the wood members had neither been burned down nor transported elsewhere yet. Although the rammed earth foundations were weathered and eroded, they were nearly the only reminders that survived up to the present on account of their immobility. The leftovers from the distant past would deeply affect subsequent urban development. In this regard, the eternal city of Rome served as an intriguing antithesis. Superimposing right upon or keeping distance away from the ancient ruins demonstrated only two of the possibilities. To most of the cities, piles of debris could be seen as a historical burden. For a city prone to floods like Rome, nevertheless, imperishable debris might not be that troublesome for it could be used to raise the ground. And also the gradual uplift of artificial terraces unexpectedly buried and preserved the historic cities of Rome in various phrases. On the contrary, the spatial temporalities of the city Chang'an exhibited both on reused materials and relocated sites made the vestiges obscurer to discern and simultaneously called for the redefinition of "authenticity".

\section{Conclusions}

This article analyzes the cause and the formation of ancient Rome's vertically superimposed urban layers as well as Chang'an's horizontally dispersed evolving patterns. Just because later developments kept their distance from the former ones, either at altitude or latitude, they could all possibly be retained without being erased like a palimpsest. Apparently, how these historic relics, nowadays cultural heritage sites, were originally situated and distributed

42. Arthur F. Wright argues that in ancient China, "whatever the hopes of a dynast for the perpetuation of his house and his empire, the building of an enduring capital would have been symbolically irrelevant." See Arthur F. Wright, "Symbolism and Function: Reflections on Chang'an and Other Great Cities," The Journal of Asian Studies, 4 (1965): 678. Michèle Pirazzoli-t'Serstevens similarly pointed out that "China has never linked its destiny with the transient fate of its material realizations". See Michèle Pirazzoli-t'Serstevens, Living Architecture: Chinese (New York: Grosset and Dunlap, 1971), 12. 
will greatly impact on the contemporary practice of heritage conservation, tourism and urban development.

Following the rapid urban sprawl of contemporary Xi'an in the past decades, the serial sites of abandoned former capitals were incorporated into the metropolitan region again one after another. The more outlying the heritage sites, the later they were dealt with in the urban agenda. In addition, the farther heritage sites happened to be the ones that were more antique. Such a coincidence therefore made the spatial layout of Xi'an look like the annual ring (See Figure 4). Judging from the feasibility of realizing conservation, however, the more scattered the heritage sites, the more they were exposed to the threats of climate conditions and human activities.
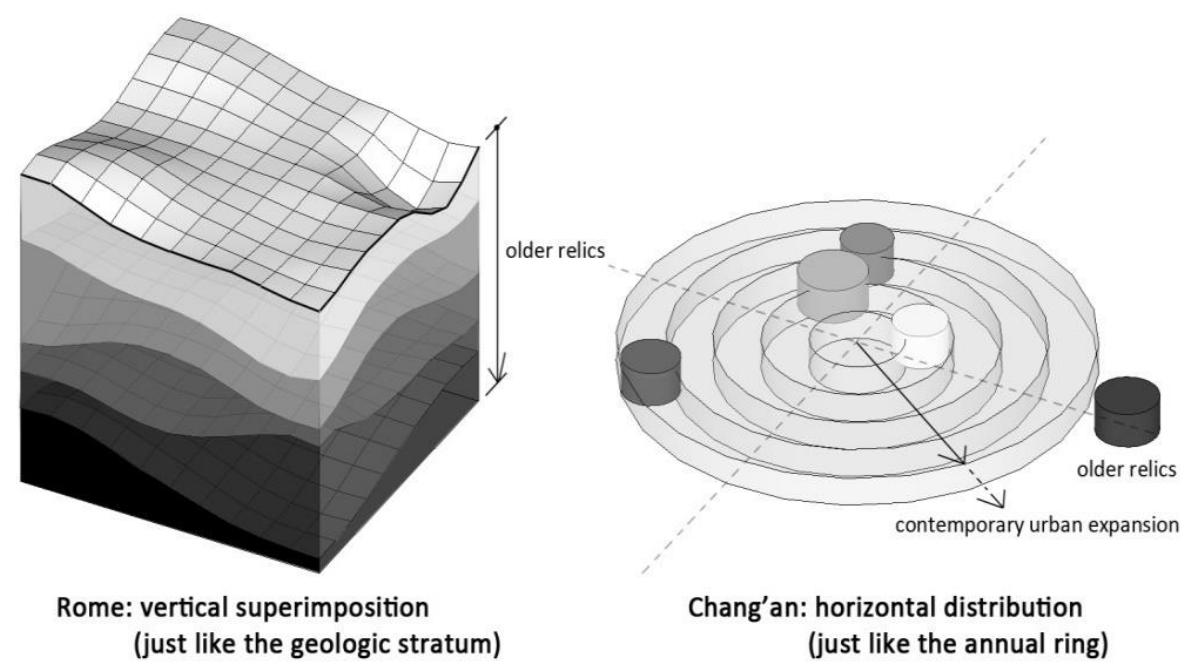

Figure 4. Comparative Urban Evolving Processes of Rome and Chang'an Source: Author.

In the case of Rome, with the aid of archeological discovery and the prosperity of the tourism industry, visitors nowadays can get a visual and sensational idea about Rome's urban history by reading the superimposed structural remains underground. The distinct layered composition made Rome's past become illustrated orderly like a geologic stratum (See Figure 4). Since the layers of Rome's masonry ruins stacked upon one another accordingly, the deeper the position usually signifies that the relics were more antique. Being buried underground helped to keep the relics relatively intact on the one hand, but on the other, it also concealed their existence and made them forgettable. It is a paradox that the historic relics could not be preserved and appreciated without excavation while the same act itself accompanied inevitable damages. Consider the weight of the layered relics based on the law of gravity, archeological excavation could only be executed according to the orders of time. Different from the isolated and independent heritage sites in $\mathrm{Xi}$ 'an, in order not to cause any harm to the upper structure in Rome, not all of the remnants beneath it could be revealed. 
The spatial particularities of the heritage sites, either scattered or aggregated, are critical to how later generations perceive, interpret, represent, and adaptively reuse the city's culture and history. While hindering and delaying the city's modernization progress, the heritage sites within the city region can also be the exclusive advantage and monopoly resources for district revitalization and promotion in the global world. Since this article deals with the cause and mechanism of such a paired temporal-spatial configuration, further investigation will be required to address the issues of the representation of respective heritage sites.

\section{Bibliography}

Aldrete, Gregory S. Floods of the Tiber in Ancient Rome. Baltimore: Johns Hopkins University Press, 2007.

Archibugi, Franco. Rome: A New Planning Strategy. London: Routledge, 2005.

De Coulanges, Fustel. The Ancient City: A Study on the Religion, Laws and Institutions of Greece and Rome. Garden City, N.Y.: Doubleday, [1864] 1956.

Dong, Zhongshu. Chunchiu fanlu [Luxuriant Gems of the Spring and Autumn]. Hefei: Huangshan shushe, [second century BCE] 2008.

Dubourdieu, Annie. "The Roman Calendar: How Did the Ancient Romans Spend their Time." Hsu, M. L. Translated. In Rome-Han: Comparer l'Incomparable, edited by Marianne Bujard and Marc Kalinowski, 329-350. Beijing: Zhonghua Book Company, 2011.

Eliade, Mircea. The Sacred and the Profane. New York: Harcourt Brace Jovanovich, [1959] 1961.

Favro, Diane. "The Street Triumphant: The Urban Impact of Roman Triumphal Parades." In Streets: Critical Perspectives on Public Space, edited by Zeynep Çelik, Diane Favro, and Richard Ingersoll, 151-164. Berkeley: University of California Press, 1994.

Gadeyne, Jan. "Short Cut: Observations on the Formation of the Medieval Street System in Rome." In Perspectives on Public Space in Rome, from Antiquity to the Present Day, edited by Smith Gregory and Jan Gadeyne, 67-83. Burlington, VT: Ashgate, 2013.

Greenhalgh, Michael. The Survival of Roman Antiquities in the Middle Ages. London: Duckworth, 1989.

Guo, Weiqi. "Shitou momie zhihou: chaoyue le paifang, citing, shibei de zhishang jianzhu" [When the Stones Effaced: The Fictitious Buildings beyond Paifang, Shrine and Stele]. Journal of Chinese Architecture History, 2 (2012): 374-395.

Han, Paothe. Zhongguo de jianzhu yu wenhua [Chinese Architecture and Culture]. Taipei: Lianjing Press, 2004.

He, Yanjie, Wei Haiyan, Xue Liang, and Li-Bili. "Jiyu zhishu fenxifa de Xi'an shi tudi liyong bianhua ji qudongli yanjiou." [A Study of the Land Use Change and the Driving Force in Xi' an City Based on Index Analysis]. Remote Sensing For Land and Resources, 2 (2009): 49-53.

Heiken, G., Funiciello, R., and de Rita, D. The Seven Hills of Rome: A Geological Tour of the Eternal City. Princeton: Princeton University Press, 2005.

Hou, Youbin. Chinese Architectural Aesthetics. Beijing: China Building Industry Press, 2009. 
Lanciani, Rodolfo. The Ruins and Excavations of Ancient Rome. Boston and New York: Houghton, Mifflin and Company, 1897.

Liang, Sicheng. Zhongguo jianzhu shi [History of Chinese Architecture]. Taipei: Mingwen Press, [1944] 1981.

Maspero, Henri. China in Antiquity. Amherst: University of Massachusetts Press, [1927] 1978.

Pan, Guxi ed. Zhongguo gudai jianzhu shi [History of Ancient Chinese Architecture]. Beijing: Zhongguo jianzhu gongye chubanshe, 1999.

Pirazzoli-t'Serstevens, Michèle. Living Architecture: Chinese. New York: Grosset and Dunlap, 1971.

Qiu, Lihui. Gudai huanghe zhongyou dushi fazhan qianyi yu huanjing bianhua yanjiou [City Development-Relocations and Environment Changes in the Middle Reaches of the Yellow River in History]. Ph. D. diss. University of Shaanxi Normal University, 2008.

Richardson, L. A New Topographic Dictionary of Ancient Rome. Baltimore: John Hopkins University Press, 1992.

Rykwert, Joseph. The Idea of a Town: The Anthropology of Urban form in Rome, Italy and the Ancient World. London: Faber and Faber, 1976.

Schneider, Rolf M. "Image and Empire: The Shaping of Augustan Rome." In Conceiving the Empire: China and Rome Compared, edited by Fritz-Heiner Mutschler and Achim Mittag, 269-298. Oxford: Oxford University Press, 2008.

Sennett, Richard. Flesh and Stone: The Body and the City in Western Civilization. New York: W.W. Norton, 1994.

Seo, Tatsuhiko. Chōan no Toshi Keikaku [City Planning in Chang'an]. Tokyo: Kōdansha, 2001.

Sima, Qian. Shiji [Records of the Grand Historian]. Hefei: Huangshan shushe, [91 BCE] 2008.

Teng, Chixian. Xinyi Shijing duben [Reader of The Book of Odes, with new annotations and translation in Chinese]. Taipei: Sanmin Shuju, 2006.

Ventriglia, U. The Geology of the City of Rome. Rome: Amministrazione Provinciale di Roma, 1971.

Wang, Xueli. "Cong Qin Xianyang dao Han Chang'an de chengzhi chongdie (xia)" [The Overlaps of Urban Regions and Institutions from Qin Xianyang to Han Chang'an, II]. Wenbo, 6 (2007): 4-10.

Wei, Zheng. Sui Shu [Book of Sui]. Hefei: Huangshan shushe, [636] 2008.

Wright, Arthur F. "Symbolism and Function: Reflections on Chang'an and Other Great Cities." The Journal of Asian Studies, 4 (1965): 667-679.

Wright, Arthur F. "The Cosmology of the Chinese City." In The City in Late Imperial China, edited by William G. Skinner, 33-74. California: Stanford University Press, 1977.

You, Shi. "Zhongguo jianzhu buzhi mu" [Chinese Architecture: Not Merely with Timber]. The Architect, 6 (2007): 69-74.

Zhang, Hailong, Jiang Jianjun, Xie Xiuping, Wu Hongan, and Zhang Li. "Jin ershiwu nian lai Xi' an diqu tudi liyong bianhua ji qudongli yanjiou" [Analyzing Land Use Changes and Its Driving Forces in Xi An Region During the Past 25 Years]. Res 
